\title{
O PATRIMÔNIO HISTÓRICO/CULTURAL DA CIDADE DE CAMPO BOM-RS: UMA LEITURA SOBRE O URBANO E OS PATRIMÔNIOS CULTURAIS
}

\author{
The historical / cultural heritage of the city of Campo Bom-RS: a reading about \\ the urban and cultural heritage
}

\author{
Vanessa Manfio* \\ *Núcleo de Estudos Agrários (NEAG/UFRGS) - nessamanfio@gmail.com .
}

Recebido em 13/05/2021. Aceito para publicação em 07/01/2022.

Versão online publicada em 25/02/2022 (http://seer.ufrgs.br/paraonde)

Como citar esse artigo: MANFIO, V . O patrimônio histórico/cultural da cidade de Campo Bom - RS: Uma leitura sobre o urbano e os patrimônios culturais. Para Onde!?, v. 16, n. 01, p. 01-25, 2022.

\begin{abstract}
Resumo:
O município de Campo Bom, localizado na região metropolitana de Porto Alegre, foi uma área de colonização alemã no Rio Grande do Sul e dessa herança colonial surgiram equipamentos e formas urbanas que permanecem no espaço até os dias de hoje, sendo verdadeiros patrimônios culturais. Os gestores municipais estão tentando, desde a década de 1990 criar políticas para preservar os patrimônios culturais e históricos, mas encontram muitos obstáculos, entre eles a demolição de vários antigos casarões históricos e a falta de uma política implantada de patrimonização. Pensando nisto, este artigo busca discutir a respeito da noção de patrimônio cultural/histórico, articulando com a necessidade de salvaguardar os patrimônios da cidade de Campo Bom, como parte essencial da memória e vida urbana. Para isto, utilizou-se o método exploratório descritivo, bem como a coleta de dados, aplicação de questionários e a revisão de literatura. Contudo, a expectativa do trabalho é contribuir com a abordagem do patrimônio cultural no espaço urbano, especialmente em Campo Bom.
\end{abstract}

Palavras-chave: Patrimônio cultural/histórico. Espaço urbano. Campo Bom/RS.

\begin{abstract}
:
The municipality of Campo Bom, located in the metropolitan region of Porto Alegre, was an area of German colonization in Rio Grande do Sul and from this colony emerged equipment and urban forms that remain in space to this day, being true cultural heritage. Since the 1990s, municipal managers have been trying to create policies to preserve cultural and historical heritage, but gain many years, including the demolition of several old historic mansions and the lack of an implemented heritage policy. With this in mind, this article seeks to discuss the notion of cultural / historical heritage, articulating it with the need to safeguard the heritage of the city of Campo Bom, as an essential part of memory and urban life. For this, the descriptive exploratory method was used, as well as data collection, application of questionnaires and literature review. However, the expectation of the work is to contribute to the approach to cultural heritage in the urban space, especially in Campo Bom.
\end{abstract}

Key-words: Cultural / historical heritage. Urban space. Campo Bom / RS. 


\begin{abstract}
Resumen:
El municipio de Campo Bom, situado en la región metropolitana de Porto Alegre, fue un área de colonización alemana en Rio Grande do Sul y de esta herencia colonial surgieron equipamientos y formas urbanas que permanecen en el espacio hasta nuestros días, siendo verdadero patrimonio cultural. Desde la década de 1990, los administradores municipales han estado tratando de crear políticas para preservar el patrimonio cultural e histórico, pero enfrentan muchos obstáculos, incluida la demolición de varias casonas históricas antiguas y la falta de una política patrimonial implementada. Con eso en mente, este artículo busca discutir la noción de patrimonio cultural/histórico, articulando con la necesidad de salvaguardar el patrimonio de la ciudad de Campo Bom, como parte esencial de la memoria y de la vida urbana. Para ello, se utilizó el método exploratorio descriptivo, así como la recolección de datos, aplicación de cuestionarios y revisión de literatura. Sin embargo, la expectativa de la obra es contribuir al abordaje del patrimonio cultural en el espacio urbano, especialmente en Campo Bom.
\end{abstract}

Palabras clave: Patrimonio cultural/histórico. Espacio urbano. Campo Bom/RS.

\title{
1 INTRODUÇÃO
}

A história e a cultura das cidades são elementos marcantes, demonstrativos de uma expansão urbana que se processa no tempo e no espaço. Neste sentido, a questão patrimonial tem se tornado, recentemente, uma febre, por parte de algumas entidades e pessoas, de cidades brasileiras por representar uma maneira de salvaguardar signos e símbolos da identidade urbana e da construção de um povo (ALMEIDA, 2013). O patrimônio é a relutância da manutenção de formas e de vidas passadas da cidade, propondo a construção de memórias e identidades com o espaço urbanizado e em mutação constante.

No entanto, nem todas as cidades brasileiras salvaguardam os seus bens patrimoniais, com políticas públicas e com educação patrimonial. Os elos da história com a modernidade ficam escondidos atrás das paredes das construções ou da demolição das formas urbanas antigas. O moderno invade o passado e o arrebata, isto é, a cidade moderna cresce e dessa forma destrói o antigo, em prol da nova especulação imobiliária e da arquitetura contemporânea. Diante disso, se faz necessário pensar e debater o espaço urbano e os patrimônios culturais/históricos.

Em Campo Bom, na cidade, os bens patrimoniais vem sendo objetos de políticas públicas destinadas à preservação e à conservação. Estas políticas se intensificam a partir da década de 1990, mas ainda encontram resistência da sociedade e desarticulação política, pois os inventários não possuem o poder de gerar políticas de tombamento patriominial e preservação espacial. Mais, recentemente, as políticas passaram a dar mais ênfase, neste sentido, e com isto sinalizam uma perspectiva de avanço, mesmo percorrendo um longo caminho ainda para se alcançar uma verdadeira memória dos patrimônios culturais/históricos frente à expansão urbana. 
Desse modo, este artigo busca discutir a expansão urbana de Campo Bom-RS, articulando esta análise com a abordagem dos bens patrimoniais culturais e históricos presentes na cidade. Para tal, utilizou-se nesta pesquisa o método exploratório descritivo, além dos recursos metodológicos, tais como: a aplicação de questionário, a revisão de literatura e a coleta de dados. Em função da pandemia COVID-19, 0 trabalho de campo não pode ser realizado. Os questionários foram aplicados aleatoriamente com pessoas da comunidade e antigos moradores de Campo Bom, por meio do sistema eletrônico e canal digital, se utilizando do google forms.

Quanto à área de estudos, destaca-se: a cidade campobonense, pertencente ao município de Campo Bom (figura 1). O município e sua área urbana encontram-se localizados na região metropolitana de Porto Alegre no Rio Grande do Sul, Brasil. Especificamente "Campo Bom situase no Vale do Rio dos Sinos, a cinquenta quilômetros de Porto Alegre e também próximo a Serra Gaúcha. Este espaço foi colonizado, principalmente, por germânicos que deixaram como legado cultural seu estilo de vida e economia [...]" (NUNES, p. 284, 2018).

Figura 1 - Mapa de localização do município de Campo Bom-RS

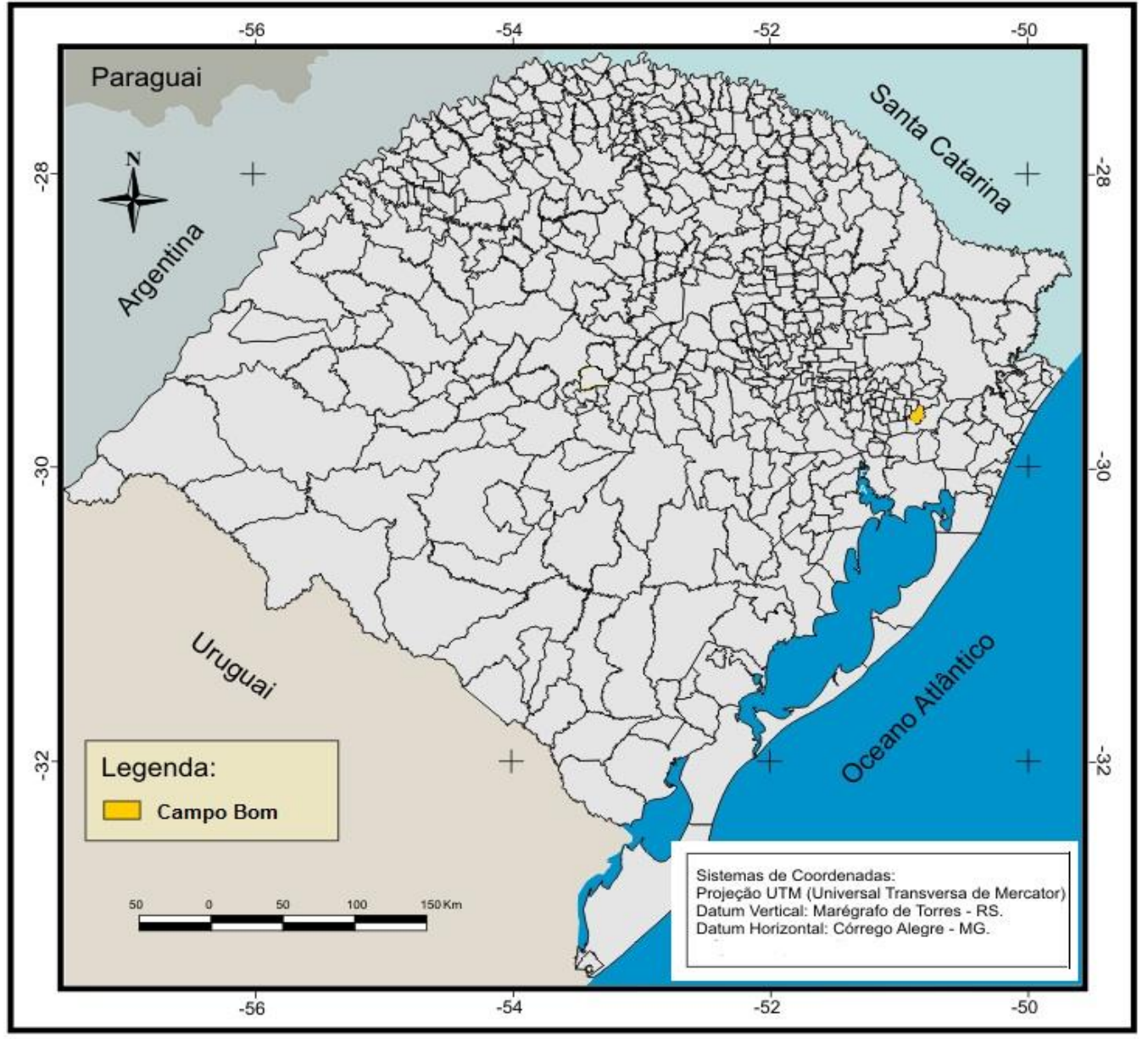

Fonte: IBGE, 2010.

Org. MANFIO, V. (2021) 
A colonização alemã favoreceu o desenvolvimento local e a construção da cidade, bem como a sua organização em vários sentidos, quanto às formas, às funções, etc. Além de ter deixado um legado em construções. Nesta ótica, o próprio processo histórico impactou no espaço, deixando bens históricos espalhados no solo urbano. É relevante, então, trazer a tona esta discussão, a fim de contribuir com a preservação e a conservação da história, memória e cultura de Campo Bom, como parte fundamental do progresso e da sustentabilidade urbana.

Espera-se, desse modo, contribuir com o pensamento e 0 tratamento do assunto junto à academia e à comunidade, possibilitando um novo olhar para a mémoria urbana de Campo Bom, reforçando a importância do reconhecimento e da criação de ações de preservação dos bens históricos e culturais, porque somente com a elaboração de um planejamento urbano e de políticas públicas que integrem estes bens é possível salvagardar-los para as gerações futuras, como parte da cidade.

\section{O ESPAÇO URBANO E OS PATRIMÔNIOS CULTURAIS: ASPECTOS TEÓRICOS}

A crescente urbanização das cidades no Brasil, fugaz na década de 1990 e 2000, colocou muitas construções antigas literalmente no chão, isto é, as antigas formas urbanas aos poucos vão sendo substituídas por prédios modernos. E a história da cidade fica na memória apenas dos moradores mais velhos ou de documentos presentes nos museus e bibliotecas. Nesse sentido, Lummertz (2013, p.11) escreve que, "Se uma cidade é despossuída de seu patrimônio cultural, poucos moradores sabem de sua própria história e quando sabem, existe pouca memória coletiva e social". Uma cidade sem patrimônios históricos e culturais torna-se vazia, sem um conteúdo que se apresente para dentro das formas urbanas, sem uma relação sensível da sociedade com o espaço.

Assim, o patrimônio cultural/histórico é tudo que representa uma sociedade e a identifica. De acordo com Choay (2014), patrimônio é uma palavra bela e antiga que esteve ligada à noção familiar e jurídica $e$ que ao longo do tempo adquiriu um significado mais amplo, ora tornouse patrimônio histórico de ussufruto de uma sociedade através de objetos que congregam um passado, tais quais, arte, construções, trabalhos, saberes e conhecimento humano. Ampliando este debate Vallbona e Costa $(2003$, p.10) consideram patrimônio cultural como "O repertório inacabado de testemunhos materiais e imateriais que constituem as referências da memória coletiva, o acúmulo das experiências que estas sociedades guardam em sua retina".

O patrimônio histórico/cultural é representado por bens diversos, tangíveis (concretos e visíveis, como casas, monumentos) e intangíveis 
(pessoas, ensinamentos, tradições, etc). Para Mautone (2001), o bem cultural é uma concepção que envolve desde o patrimônio monumental, documentos e bens histórico, arqueológico, cultural até mesmo o ambiente natural. Completa este entendimento Almeida (2013) afirmando que o bem cultural é um produto de concepção humana, com valor singular qualquer e pode representar um testemunho, um registro ou um documento da história do homem. Desse modo, Menezes (2009, p.3) coloca que,

Os bens patrimoniais são materialidades e práticas culturais que se destacam no tecido urbano e nas manifestações populares por mediarem diferentes e memoráveis fatos históricos e personagens ilustres ou por representarem heranças culturais, técnicas e estéticas de tempos passados.

Nas palavras de Greffe (2003), reforçando essa noção, o patrimônio é como um ecossistema, formado por elementos interdependentes, que juntos produzem laços sociais e equilíbrio espacial, implicando numa sinergia entre o valor patrimonial e a melhoria da qualidade da paisagem urbana e natural. Neste entendimento, o patrimônio cultural é uma forma de favorecer a sustentabilidade urbana, a qualidade da paisagem e o auto-reconhecimento da população ao seu espaço sensível de história e memória, constituindo-se num espaço urbano com identidade cultural e harmonia entre o velho e o novo.

Todavia, as discussões a respeito dos patrimônios e bens culturais é uma abordagem recente, do século $X X$ e vinculada ao desenvolvimento do turismo de caráter cultural (ALMEIDA, 2013). Neste ponto, "o patrimônio deixa de ser valioso por sua significação na história e passa a ser valioso porque pode ser 'vendido' como atrativo turístico" (BARRETTO, 2000, p.32). Para Schlüter (2003), o desenvolvimento do turismo cultural, nos últimos anos, permitiu a conversão do patrimônio em um recurso de exploração das cidades, principalmente com a criação de museus e a recuperação de exemplares históricos das cidades que se transformaram-se em protagonistas da vida cultural. Dessa forma, a associação entre patrimônio e turismo permite a preservação, pois cria mecanismos para que os proprietários mantenham os espaços históricos e queiram salvaguardá-los, além de garantir ao poder público à gestão e às ações para tal efeito.

Conforme Pinheiro (2013), o patrimônio histórico-cultural é uma importante ferramenta para a atividade turística, assim como para população que se beneficia dos legados da cidade para valorização cultural e social. Sobre o assunto os autores Garcia; Zottis e Bonho (2015, p.69) complementam que, "A importância para a comunidade advém da sua relação de valor, do conhecimento de suas práticas e saberes, resultando na valorização e preservação de seu legado histórico, além da ampliação da noção de autoestima e cidadania".

Então, o patrimônio natural e patrimônio cultural passam por um processo de "patrimonialização", marcado pelo processo de tombamento, sua conservação e manutenção, pelas políticas públicas (LUMMERTZ, 
2013). Logo, o surgimento de órgãos e entidades que registram, fiscalizam e geram reconhecimento nacional e mundial dos bens culturais de uma cidade ou espaço qualquer foi relevante ao domínio de abrangência do patrimônio perdido nas áreas urbanas. Entre estes organismos estão: a Organização das Nações Unidas para a Educação, a Ciência e a Cultura - UNESCO, e no Brasil, especificamente, a Constituição de 1988, deu o pontapé inicial à patrimonização, e hoje o Instituto do Patrimônio Histórico e Artístico Nacional-IPHAN é um órgão com expressiva competência neste âmbito.

As ciências humanas também apresentam uma contribuição significativa, pois permitem a discussão acadêmica e a participação em projetos juntos à comunidade. Entre estas ciências está a geografia com seu olhar para a memória das cidades. Nesse sentido, "A geografia não tem, pois, que se definir como o estudo presente. É possível sim fazer geografias do passado" (ABREU, 2000, p.16). Ainda, Abreu (1998, p.20) afirma que, "A geografia tem muito para contribuir para a discussão e recuperação da memória das cidades", contribuindo com a carência de trabalhos de recuperação das cidades, de valorização da memória coletiva e revelando o enquadramento espaço-temporal do espaço (ABREU, 1998). A geografia pode servir para fazer uma evolução da cidade, tratar os fragmentos deixados pelo passado no espaço e reconhecer objetos e sistemas de ação que fornecem o entendimento do passado e do presente (ABREU, 2000). Porém, a resposta da ciência geográfica ainda é limitada, com poucos trabalhos e embasamentos teóricos, bem como a precária noção temporal/escalar da cidade em sua evolução socioespacial (ABREU, 1998). Desse modo, um novo caminho a se percorrer na geografia é a sua participação no tema memória das cidades ou no tocante do passado como alicerce do presente e de projeção ao futuro.

Como dizemos anteriormente, as cidades são heranças do trabalho e dos tempos diversos e, sua compreensão é salutar para manter o direito ao passado e a memória urbana. Para tal, é necessário preservar os patrimônios culturais e históricos, porque eles são o ponto-chave desta emblemática discussão. Como afirmam Ribeiro e Simão (2014), a cidade deve espelhar políticas e ser portadora de história, caso contrário irá se negar uma parte fundamental dela que é as mémorias. Logo,

A cidade, ao ser compreendida pelo seu duplo caráter contraditório de obra e produto, carrega na sua constituição a condição de ser um artifício humano, fruto do trabalho social. Sendo realização humana, descola-se da noção de natureza e adentra a noção de história, a noção de transformação. É por esta razão que a cidade pode ser encarada [...] fruto de ações políticas e, obviamente, portador de história (RIBEIRO; SIMÃOS, 2014, p. 3).

Por outro lado, o que não se pode perder de vista na patrimonização de bens de uma cidade é que preservar estes não deve significar apenas a substituição do patrimônio de um grupo social por outro, ou seja, deixar as formas e monumentos no espaço, mas sim demonstrar a pluralidade de vivências ali espacializadas, possibilitando a identificação e memória 
de uma significativa parcela da sociedade (AURELIO; SCALABRINI, 2004). Porque quando não se demonstra o valor destes patrimônios, "o papel da preservação do patrimônio urbano como mero registro do passado, como representação monumental e simbólica das vitórias do poder e assim perpetuada, é relativizado e minimizado" (RIBEIRO; SIMÃO (2014, p.6). Ora o patrimônio vai além de escolher bens de um legado histórico, mas criar um sentimento de pertencimento e reconhecimento destes como a essência da sociedade e das cidades, como um contador de história e de vida. E assim, "o patrimônio deixa de ser a seleção pura e simples de alguns monumentos pontuais, destacados na paisagem e devidamente sacralizados, passando a fazer parte da própria dinâmica social" (AURELIO; SCALABRINI, 2004, p.2).

Preservar não é meramente utopia, fundamentada em projetos de pessoas e entidades que buscam a nostalgia e o passado, que vão contra a contemporaneidade da cidade. Sabe-se que a moderna vida urbana e a globalização transformam a cidade em mercadoria e os espaços passam a ser o afã do consumismo, da especulação imobiliária, então, preservar é antes de tudo uma atitude política, uma maneira de resistência à transformação do espaço em mercadoria, à homogeneização espacial, que recriam as cidades tornando-as cada vez mais parecidas umas com as outras (AURELIO; SCALABRINI, 2004).

Nas palavras de Choay (2014, p.12), a autora expõe a necessidade de pensar o patrimônio para além da verificação e do imediatismo.

[...] o patrimônio histórico exige, pois mais do que uma verificação de prazer. Exige um questionar, uma vez que é revelador, negligenciado e, contudo, incontestável, de um estudo da sociedade e das questões que nela exige (CHOAY, 2014, p.12).

Contudo, o sentido de preservar as formas urbanas patrimoniais devem se valer de instrumentos sólidos, de legislações e de medidas que não simplesmente registre os bens culturais, mas lhes dê sinônimo de manutenção e não seja um obstáculo ao proprietário que terá que arcar com a manutenção sem exploração física e social. Então, "É urgente aproximar os ideais de preservação do patrimônio à realidade prática do planejamento urbano. Trata-se de um desafio a ser vencido e requer o exame cauteloso das ferramentas e estratégias disponíveis em cada caso" (MAIA; FARIAS FILHO, 2015, p.187). Este trabalho requer registro, ações, educação patrimonial, consulta popular, entre outras medidas.

Ainda, é importante que a valorização dos bens do passado não virem uma alegoria, isto é, um culto particular e sem identidade coletiva, que permaneçam no espaço, por meio de uma mercantilização dos patrimônios e do espaço, mas que eles atinjam verdadeiramente uma memória urbana (CHOAY, 2014). O passado vivo na cidade precisa ser um contraponto ao moderno, mas precisa assumir funções junto ao espaço, sendo estas culturais ou sociais, um prédio em ruína, em vias de desabamento não representa uma memória de interesse a sociedade, pois põe em risco a população. Doravante uma especulação imobiliária e uma mercantilização do espaço geram segregação e turistificação, 
descaracterizando o verdadeiro sentido do patrimônio cultural/histórico, assim como a desvalorização e o abandono também o fazem.

Logo, educar a sociedade para valorizar o seu passado se faz necessário frente à intensa urbanização e à mercantilização do espaço, porque toda cidade é mais que o concreto urbano é a essência das múltiplas vivências, relações, contradições. Sem dúvida, é importante a população local fazer parte da escolha e do reconhecimento dos seus bens culturais, para que a mesma tenha consciência de conservá-los. Enfim, salvaguardar os bens culturais e históricos é guardar e mostrar, conservar e utilizar o bem como um acessório urbano, como parte de uma sociedade.

\section{A CIDADE DE CAMPO BOM E SEUS PATRIMÔNIOS HISTÓRICOS E CULTURAIS}

A cidade de Campo Bom se desenha a partir da construção de um povoamento espontâneo, principalmente em decorrência da concessão de sesmarias, da passagem de tropeiros e da colonização alemã na região. Os tropeiros foram responsáveis por registros do local, por relações que envolviam o espaço campobonense. Como afirma Ferreira (2004), anteriormente à chegada dos colonos, os tropeiros cruzavam o vale do Rio dos Sinos, na altura da hoje cidade de Campo Bom, dos quais os campos apropriados para o gado, com excelentes pastagens e água, impetravam paradas obrigatórias e relações comerciais e daí a origem do nome do município.

A partir da Colônia Alemã de São Leopoldo - fundada em 25 de julho de 1874 -, às margens do Rio dos Sinos, houve a demarcação das terras, que compreendem o atual município de Campo Bom, assim entre dezembro de 1825 e janeiro de 1826, os primeiros imigrantes chegaram na localidade que hoje fica o bairro Porto Blos, iniciando a ocupação e colonização deste espaço (GEVEHR; CASTRO, 2019). Com a chegada de mais imigrantes estes foram se direcionando para outras áreas próximas, ampliando o povoamento regional, que posteriormente daria origem aos municípios, entre eles Campo Bom. Estes espaços se formam por meio da relação sociedade e natureza que se articula localmente. $O$ imigrante constrói e altera a paisagem local em detrimento das suas necessidades e impõe nesta região, as margens do Rio Sinos, uma concentração urbana. Conforme Gevehr e Castro (2019, p.29),

O desenvolvimento urbano de Campo Bom é resultado de um processo, que muitas vezes, foi imposto pela própria natureza e, por um conjunto de especificidades, que acabaram por moldar não só o município, mas também outros que fazem parte da região de imigração alemã.

Essa condição de ocupação e transformação do espaço pelo imigrante resultou na construção de casas, no desenvolvimento de 
indústrias, olarias, madeireiras, entre outras, bem como na organização da cidade e do campo, a partir do trabalho e da cultura alemã. Porque mesmo o imigrante, que inicialmente desenvolveu a agricultura, por conta das suas aptidões e saberes artesanais este passou a desempenhar atividades industriais e artesanais, favorecendo a produção do espaço urbano. Em virtude disso, a economia do município se baseia atualmente no setor industrial. Como afirma Borba (1996, p. 258),

\begin{abstract}
Desde a colonização, a economia de Campo Bom orientou-se para a indústria. Embora a atividade básica a que se dedicavam os primeiros colonos fosse à agricultura, muitos eram, simultaneamente, agricultores e artesãos (marceneiros, ferreiros, curtidores, sapateiros, seleiros, alfaiates). Compreensivelmente, as primeiras instalações industriais foram para beneficiamento de produtos agrícolas moinhos de grãos e de azeite, atafonas e engenhos de cana-deaçúcar -, à semelhança do que acontece em tantas outras colônias, no Rio Grande do Sul. Duas atividades logo se destacaram: a indústria oleira e a curtição e fabricação de derivados do couro.
\end{abstract}

A expansão urbana parte da localidade Porto Bloss, área próxima ao Rio dos Sinos, e avança em direção ao atual centro de Campo Bom e ao longo deste trajeto ocorre a construção das primeiras casas e dos espaços públicos. Estes seguiram ao longo de uma avenida principal, batizada de Avenida Brasil, que ligava o espaço ao seu entorno. Para Copstein (1964), a Avenida Brasil foi o principal acesso da cidade, o primeiro ponto de povoamento, onde surgiram casas (algumas enxaimel), igreja, escola e cemitério. Dessa forma, a cidade se constitui aos poucos fruto da organização das famílias e da integração dos núcleos urbanos, posteriormente cidades da região. Reforça este assunto, Silveira (2001, p.64),

A cidade iniciou-se a partir de um traçado, longo, da hoje Av. Brasil, na direção leste-oeste, sendo ela o divisor principal dos primeiros lotes rurais. É natural que ao longo desta via surgissem os primeiros prédios e os primeiros rudimentos de povoamento, o que ocorreu também à beira d'água, nas margens do rio dos Sinos. $\mathrm{O}$ primeiro meio de comunicação com a Capital e outras cidades com as quais o povoamento efetuava trocas foi o rio dos Sinos, e desta forma justificam-se os dois primeiros locais de assentamento.

Estes dois locais de povoamento da atual Campo Bom foi, então, o bairro Porto Blos, próximo ao rio dos Sinos, e o centro, cortado pela avenida Brasil, depois a cidade se espalha em outras direções, construíndo bairros e loteamentos urbanos. A implantação de infraestruturas como rodovias e interligações de transportes entre as cidades também favoreceu o desenvolvimento urbano e a expansão da cidade campobonense.

Neste ponto, a construção da linha férrea Porto Alegre-Taquara trouxe alterações as vilas constituídas ao longo da região, e influenciou de forma expressiva Campo Bom, pois a inauguração da estação férrea atraiu indústrias, casas de comércio e a expansão do povoado (COPSTEIN, 1964). Assim, a área urbana de Campo Bom ganha segmento com a construção da Estação ferroviária e passa a redirecionar 
o fluxo urbano para esta direção da cidade e ao longo da ferrovia, atual bairro centro. Mas, somente na década de 1920 que a planta urbana da cidade começa a se desenhar nitidamente, adquirindo características próximas da planta atual da cidade campobonense (COPSTEIN, 1964).

Diante disso, a urbanização da cidade permeia esta área central, da estação férrea, em direção a oeste bairro Porto Blos (figura 2), com o prolongamento da Avenida Brasil e em direção ao sudeste com a criação da avenida Presidente Vargas (COPSTEIN, 1964). Estas se constituíram em importantes avenidas que cortam hoje a cidade e que antigamente promoveram a expansão urbana de Campo Bom. Em resumo, pode-se dizer que a cidade ganha sua forma urbana, inicialmente com a vinda dos imigrantes e o seu assentamento e, posteriormente, com a criação da Estação Férrea (figura 3), que traz o desenvolvimento de indústrias e a concentração de moradias e serviços entorno de si, criando caminhos para se ampliar a urbanização para outras direções, seguindo o rio dos Sinos e as novas instalações urbanas, como ruas e outros equipamentos.

Figura 2 - Fotografia da cidade de Campo Bom em 1926

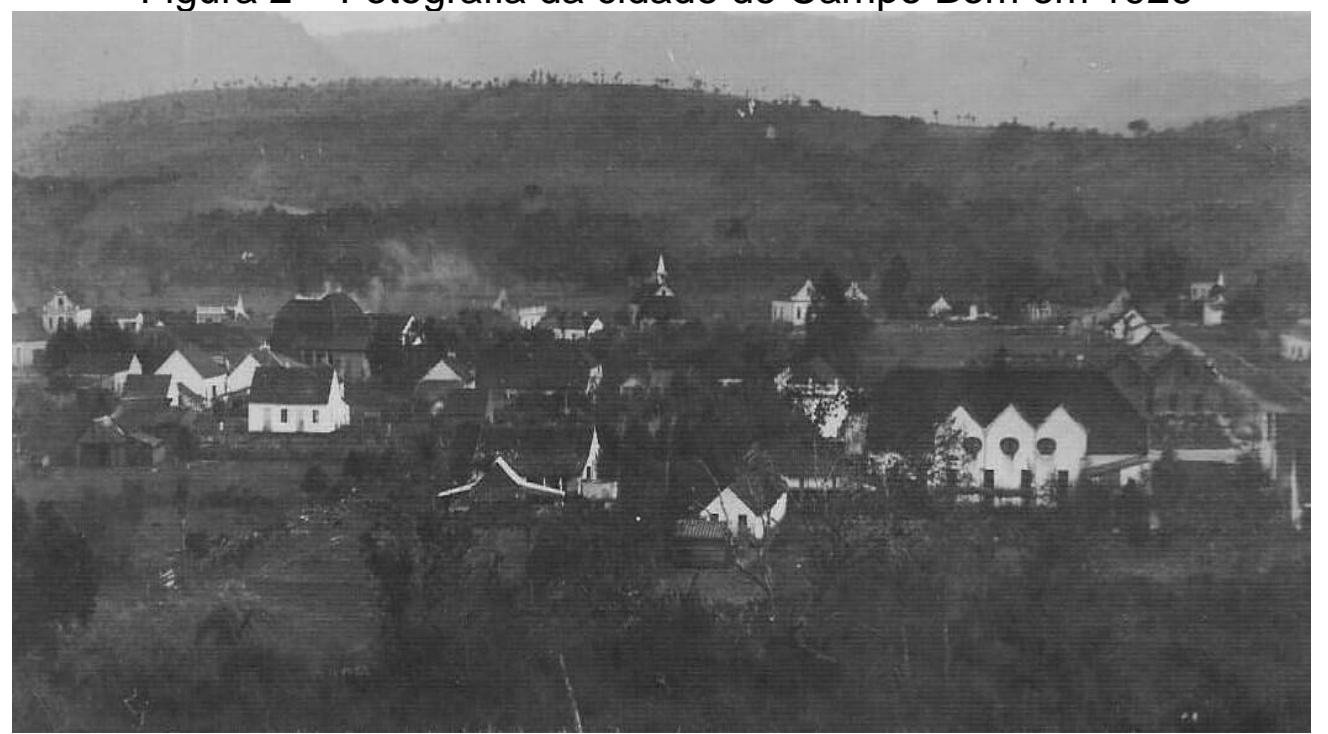

Fonte: acervo da Família Dick.

Além da Estação Férrea, a instalação e inauguração da rede elétrica da Vila (atual Campo Bom) permitiu ampliar os serviços fazendo com que no ano seguinte este aglomerado urbano fosse reconhecido como Distrito de São Leopoldo, possuindo cerca de uma população total de 1250 habitantes; seguindo como distrito até a data de 31 de janeiro de 1959, quanto o governador Ildo Meneghetti assinou a lei de criação do município de Campo Bom (GEVEHR; CASTRO, 2019). Neste percurso, na década de 1930, uma série de investimentos públicos no distrito de Campo Bom, executados pela administração de São Leopoldo (como a construção do Grupo Escolar Theodomiro Porto da Fonseca em 1933, primeira escola pública - instituída fora de uma sede municipal em todo Estado) trouxe uma nova organização da cidade (FONSECA, 1933). 
Figura 3- Área central junto a Estação Férrea

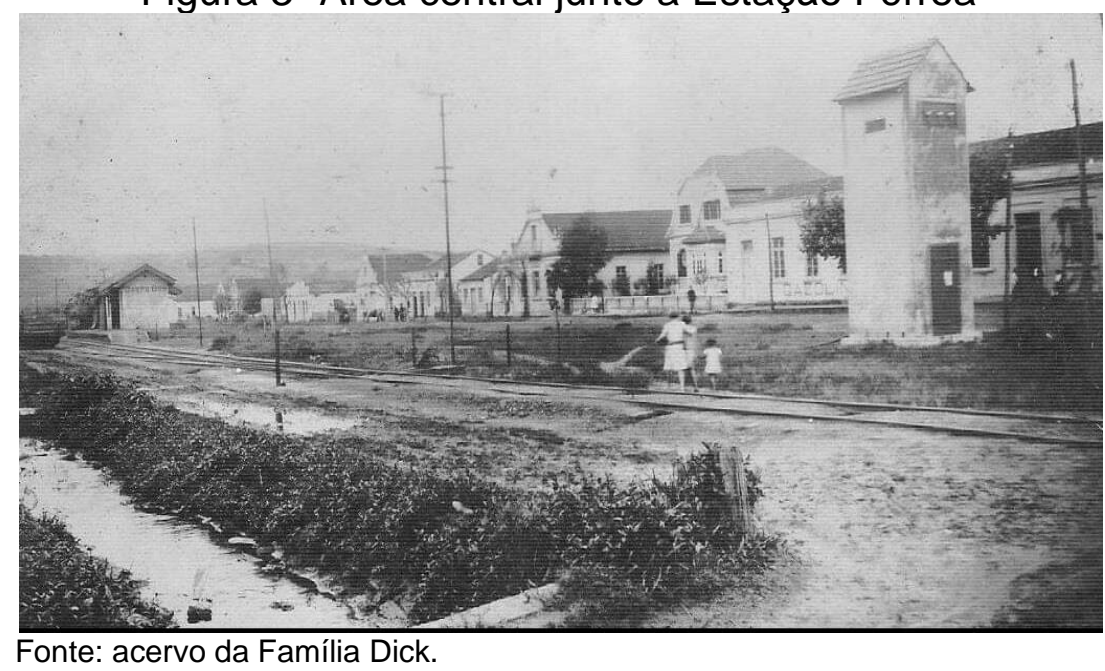

Nestas condições a expansão urbana passa a sofrer aumento populacional, expansão de forma e de função urbana. De acordo com a Prefeitura Municipal de Campo Bom (2020), o período de urbanização de Campo Bom data de 1959, juntamente com a emancipação municipal, devido à prosperidade econômica. Segundo dados do Instituto Brasileiro de Geografia e Estatística (IBGE), desde 1950 até 1980 houve um crescimento populacional no município, concentrando-se inicialmente a população de origem germânica. Completa estes dados Borba (1996), quando escreve que durante a década de 1980, a taxa de urbanização ultrapassou os $50 \%$, chegando a $68,38 \%$ em 1991, isto é a população total em 1991 era de 15.192 habitantes, dos quais 10.388 eram residentes na área urbana. Em 2010, conforme, o último censo demográfico do IBGE, o município de Campo Bom possuía 57345 habitantes residentes no espaço urbano e 2736 residentes no meio rural, demonstrando uma expressiva urbanização. Então, mais de $90 \%$ da população residem, hoje, no espaço urbano.

No que tange a urbanização, na figura 2, é possível ver Campo Bom em 1926, com poucas casas e estabelecimentos, bem como pequena concentração populacional. Enquanto, na figura 4, da década de 1980, a urbanização é expressiva e o tecido urbano bem organizado com uma nítida tendência a verticalização urbana. Na figura 4 aparecem a avenida Brasil (rua que passa pelas igrejas: Igreja Católica Santa Terezinha, Igreja Evangélica e a Antiga Igreja Evangélica) e o centro urbano em destaque. 
Figura 4- Fotografia áerea do centro da cidade de Campo Bom em 1980

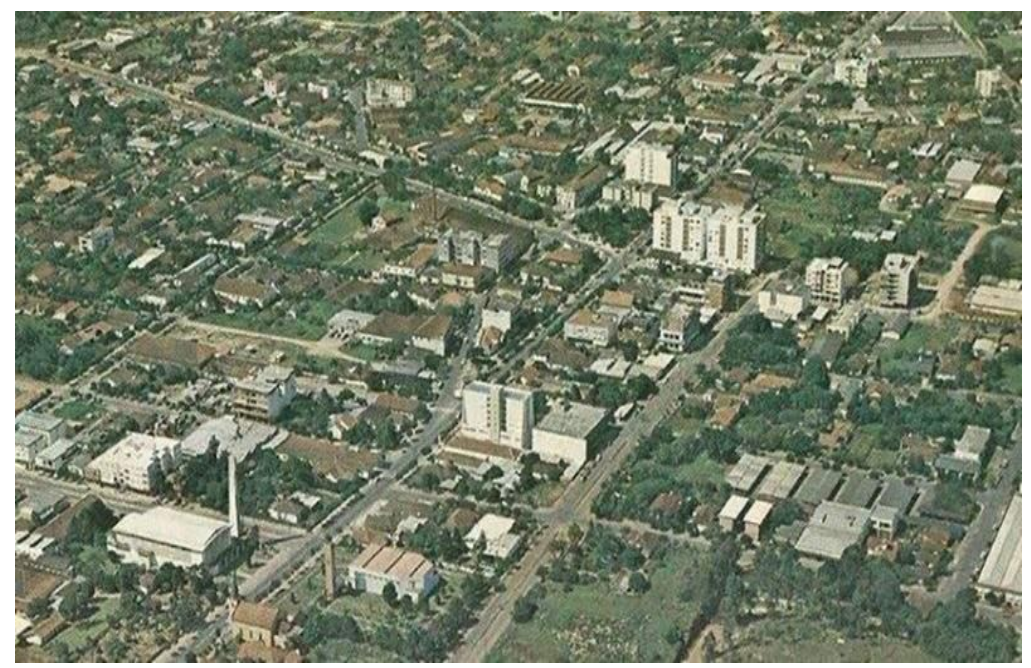

Fonte: ELLWANGER, 2019.

Já na figura 5 é possível observar a urbanização e a conurbação de leste a oeste da cidade, ao passo que em direção norte a sul a área urbanizada não apresenta manchas de conurbação, sendo ainda, a concentração urbana menos intensa. Esta condição é resultado do que foi posto anteriormente, que a cidade inicia pelo povoamento em direção a avenida Brasil no sentido leste-oeste. Como afirma Silveira (2001, p. 66) "Hoje, a urbanização de Campo Bom apresenta continuidade física com Novo Hamburgo, existindo uma conurbação a leste que impede a distinção das malhas viárias de uma e outra cidade".

Figura 5 - Imagem de satélite de Campo Bom - Conurbação leste-oeste

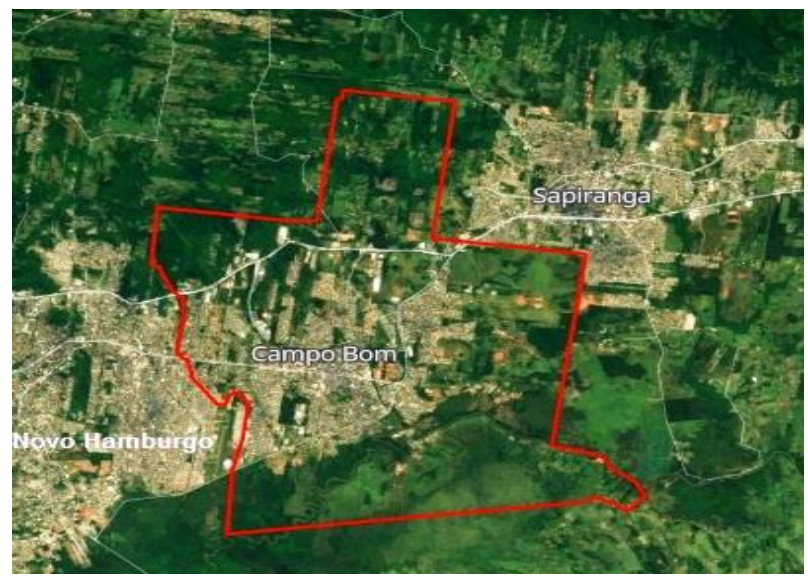

Fonte: Google earth, 2021. 
Na figura 6, entretanto, é possível observar a atual configuração do solo urbano, com a área do centro de cor vermelho escuro. Esta figura além de mostrar a concrentração da malha urbana favorece a visualização dos pontos de interesse cultural que seguem na sua maioria das margens do rio dos Sinos, no bairro Porto Blos em direção ao centro. Este recurso foi elaborado pela Prefeitura Municipal e compõe o Plano Diretor 2019, demonstrando a intenção da gestão municipal no reconhecimento dos bens históricos/culturais.

Figura 6- Mapa de interesse cultural

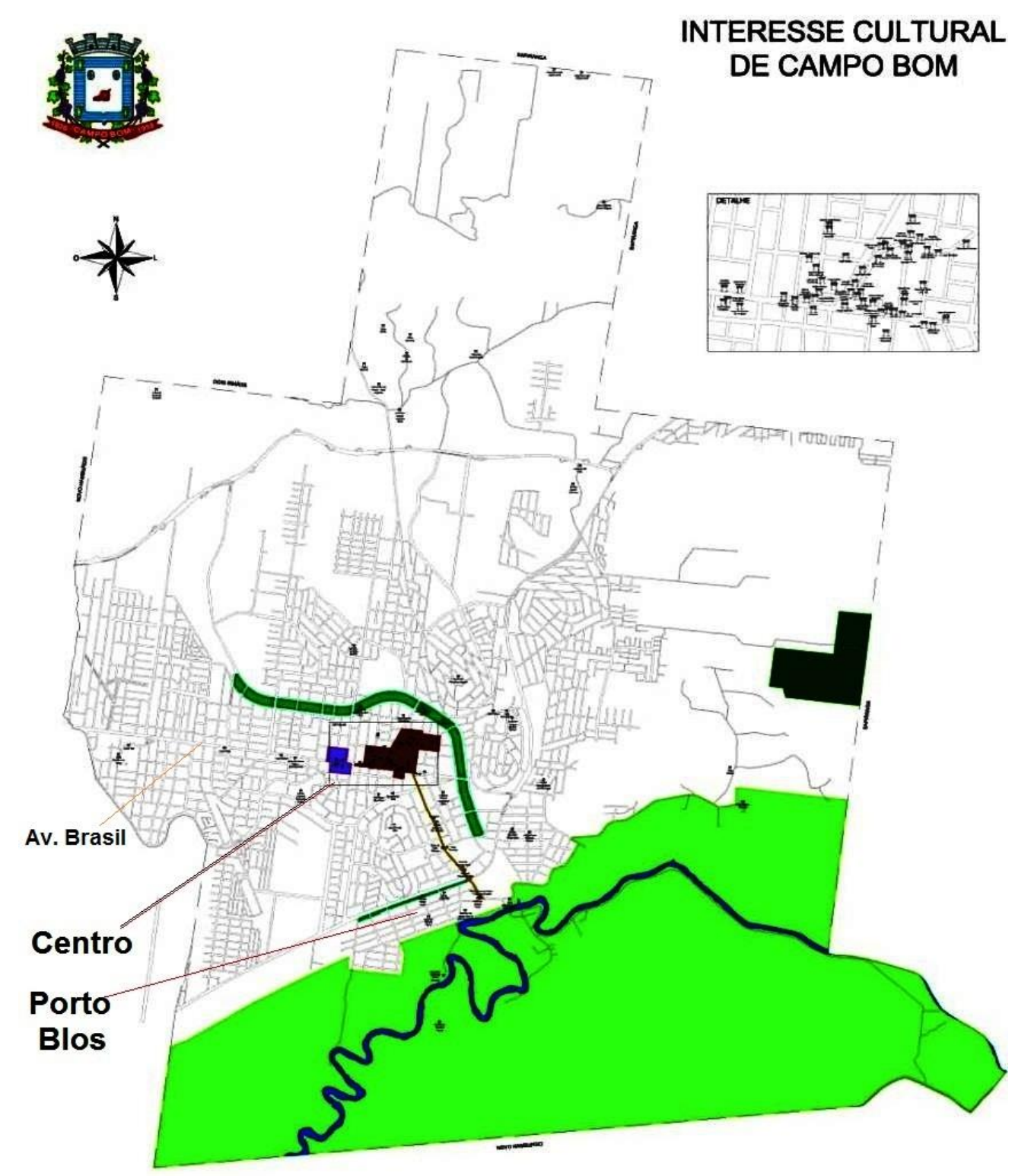

Fonte: Prefeitura Municipal de Campo Bom, 2020.

Adaptado por: MANFIO, 2021 
Noutro viéis, a população urbana de Campo Bom representou um reservatório de mão de obra operária das fábricas ali instaladas, especialmente das indústrias de calçados e do trabalho com o couro. Estas exerceram uma participação significativa na economia e no terreno urbano, na década de 1960 e 1970. Logo, a partir da emancipação do município, a cidade de Campo Bom sofre transformações urbanas ligadas ao desenvolvimento do setor couro-calçadista. Nas palavras de Gevehr e Castro (2019, p. 22),

\begin{abstract}
Os processos de migração e a urbanização, decorrentes de todo setor produtivo do calçado, contribuíram de forma preponderante para a construção - e reconfiguração - do espaço urbano de Campo Bom (RS), que está entre as cidades mais importantes do setor coureirocalçadista do sul do Brasil.
\end{abstract}

Este setor contribuiu para a constituição de formas urbanas, como fábricas, curtumes, lojas, sindicatos, monumentos. A própria construção da ciclovia de Campo Bom com percursos, que interligam toda a cidade, teve influência das fábricas calçadistas, porque os operários utilizavam a ciclovia para o seu deslocamento. Como destacam Manfio e Meier (2018, p.49), "As ciclovias estão ligadas ao fluxo diário de trabalhadores industriais, principalmente do setor de calçados, que necessitam se locomover dos bairros ao centro ou vice e versa". Hoje, é uma importante infraestrutura urbana que permite as caminhadas, mobilidade urbana e lazer.

Por outro lado, o município de Campo Bom construiu ao longo da sua história um desenvolvimento significativo não apenas no campo industrial, mas também social. Campo Bom apresenta um Índice de Desenvolvimento Humano (IDH) acima da média dos padrões brasileiros com 0,745 na escala do IDH (IBGE, 2010). Estes números são resultado do incentivo das administrações públicas nas áreas de educação e cultura, como a criação do Centro de Educação Integrada (CEI), com projetos de estímulo à literatura e uma das mais tradicionais e maiores feiras do livro do estado, entre outros (NUNES, 2017).

Então, a imigração alemã permitiu a organização da cidade, o desenvolvimento e a construção de funções urbanas. Uma das funções urbanas de Campo Bom é a industrial, pois desde a colonização se desenvolveram pequenas indústrias de beneficiamento dos produtos agrícolas, de caráter familiar e estes estabelecimentos se desenvolveram aumentando a sua extensão e participação na economia local, bem como na empregabilidade, destacando até os dias de hoje a indústria calçadista e oleira (COPSTEIN, 1964). As madeireiras também são significativas na cidade, bem como as indústrias de papel, mecânica e metalúrgica.

Juntamente com a função industrial é nítida na cidade a função comercial pelo expressivo número de estabelecimentos comerciais de varejo e venda de produtos variados, como calçados, supermercados, roupas, papel, entre outros. Para Copstein (1964) bancos, bazares, relojoarias, concessionárias, serviços médicos-hospitalares e lojas em gerais são vistas na cidade. Ainda, a instalação de uma central telefônica 
da Companhia Riograndense de Telecomunicações, com cabines para população telefonar foi um progresso que acompanhou as décadas de 1980 e 1990. Hoje, o avanço na cidade é a instalação do serviço gratuito de internet sem fio para população.

A colonização alemã também deixou marcas profundas não apenas na organização das atividades econômicas e funções urbanas, mas nas construções urbanas, isto é, na forma urbana. Estas marcas são, em partes hoje consideradas patrimônios culturais e históricos do município e da cidade de Campo Bom. A maioria desdes bens antigos estão dispostos na paisagem urbana, especialmente nos bairros Porto Blos e centro, de onde parte a urbanização inicial, como dito anteriormente. São bens que revelam a memória urbana, sinalizam a relação tempo-espaço. Por exemplo, o antigo Cinema Imperial, a Igreja Evangélica, a Estação Ferroviária, a Fábrica Irmãos Vetter são bens patrimoniais, bem como casarões históricos.

A Igreja Evangélica (figura 7) e o cemitério evangélico seguem fazendo parte da história local, dispostos ao longo da Avenida Brasil. Eles foram elementos projetados na colonização e no desenvolvimento urbano. Em 2020, a antiga igreja Evangélica de Confissão Luterana no Brasil templo da Comunidade da Trindade - foi tombada como Patrimônio Histórico e Cultural de Campo Bom, abrindo caminho para futuros reconhecimentos oficiais de outros patrimônios. O decreto № 6.970 , de 14 de dezembro de 2020 oficializou o desejo da comunidade evangélica em manter este patrimônio histórico salvaguardado (PREFEITURA MUNICIPAL DE CAMPO BOM, 2021). A Igreja acima descrita foi construída em 1828, sendo inaugurada para culto em 1851, inicialmente foi construída de madeira e depois reformada para atual forma (LANG, 1996). Hoje, ela constitui-se como peça-chave de uma história marcada também pela fé e religiosidade dos colonizadores.

A Antiga estação ferroviária (figura 8 e 9) foi, igualmente, um importante elemento de expansão urbana na construção da cidade de Campo Bom, como dito antes, e continua preservada no centro da cidade. Ela teve suas funções alteradas com o passar do tempo, abrigou a Prefeitura Municipal, a Câmera dos Vereadores, a biblioteca municipal e atualmente o centro cultural. $\mathrm{O}$ seu entorno foi marcado por antigas construções históricas, algumas delas não estão mais no espaço, apenas na memória urbana. Foi uma área com estabelecimentos industriais, comerciais, rodoviária e outros serviços, pois o movimento da Estação concentrou a urbanização ao redor da mesma. 
Figura 7 - Foto da Igreja Evangélica Luterana

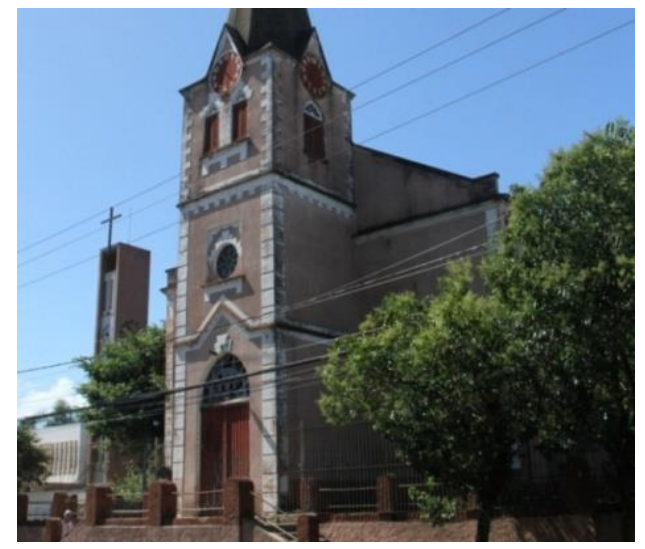

Fonte: Jornal NH, 2021.

Figura 8 e 9 - Fotografia da Estação ferroviária (antes e atual)
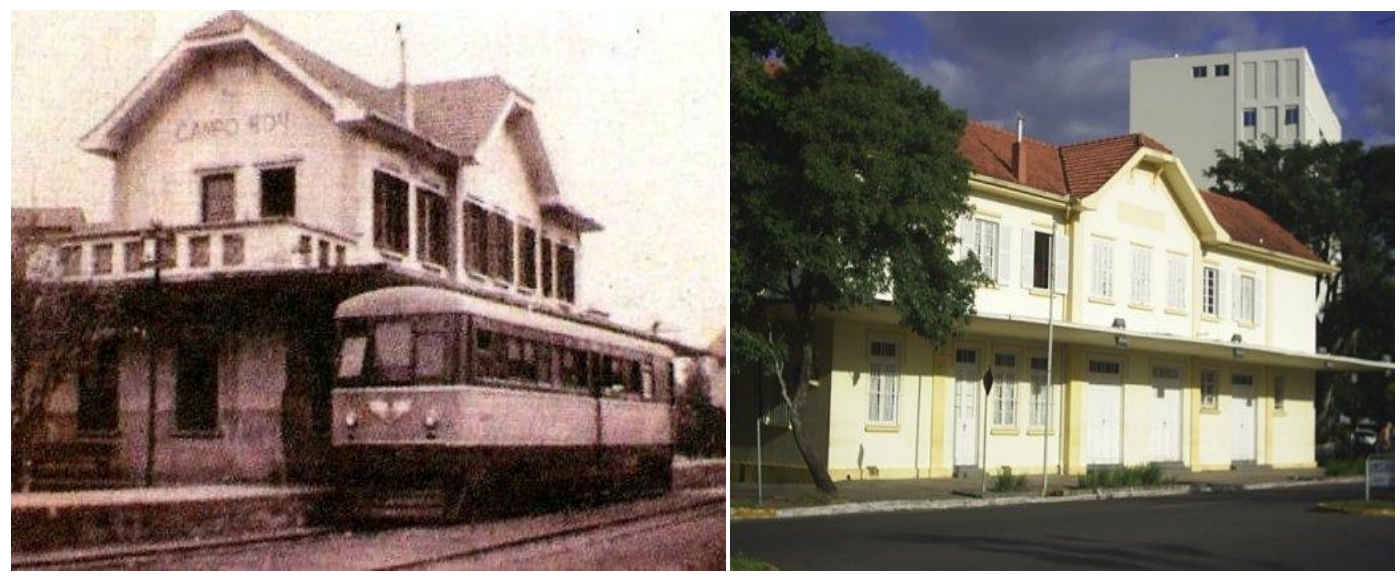

Fonte: Estações Ferroviárias do Brasil, 2020.

Outro elemento urbano importante é o prédio do Cinema Imperial. Este prédio, por muitos anos abrigou um cinema (figura 10), atualmente recebeu reformas, permanecendo com sua fachada original e também mudou de função, pois recentemente abrigava uma farmácia e casas comerciais. Segundo Lang (1996), o prédio foi inaugurado em 1930, com arquitetura no estilo eclético. Os proprietários eram Alfredo Blos e sua esposa, Danila Vetter que investiram no espaço equipando com aparelhos sonoros, escadarias para as pessoas olharem o cinema de cima - numa proposta inovadora para época (LANG, 1996; JORNAL REPERCUSSÃO, 2017). Assim, em 1930 o cinema marcou o cenário cultural com uma nova oportunidade de lazer e cultura. Este prédio encontra-se hoje em bom estado de conservação e bem localizado no centro da cidade. Os familiares dos antigos proprietários têm preservado o bem cultural e realizado reformas, devido às memórias da família. Porém, a falta de políticas públicas e a regulação destes bens públicos pelo tombamento 
dificultam a preservação e conservação, porque deixa a cargo dos proprietários a sua conservação, o que em muitos casos, representa a destruição das construções antigas frente à modernização e crescimento urbano.

\section{Figura 10- Cinema Imperial}

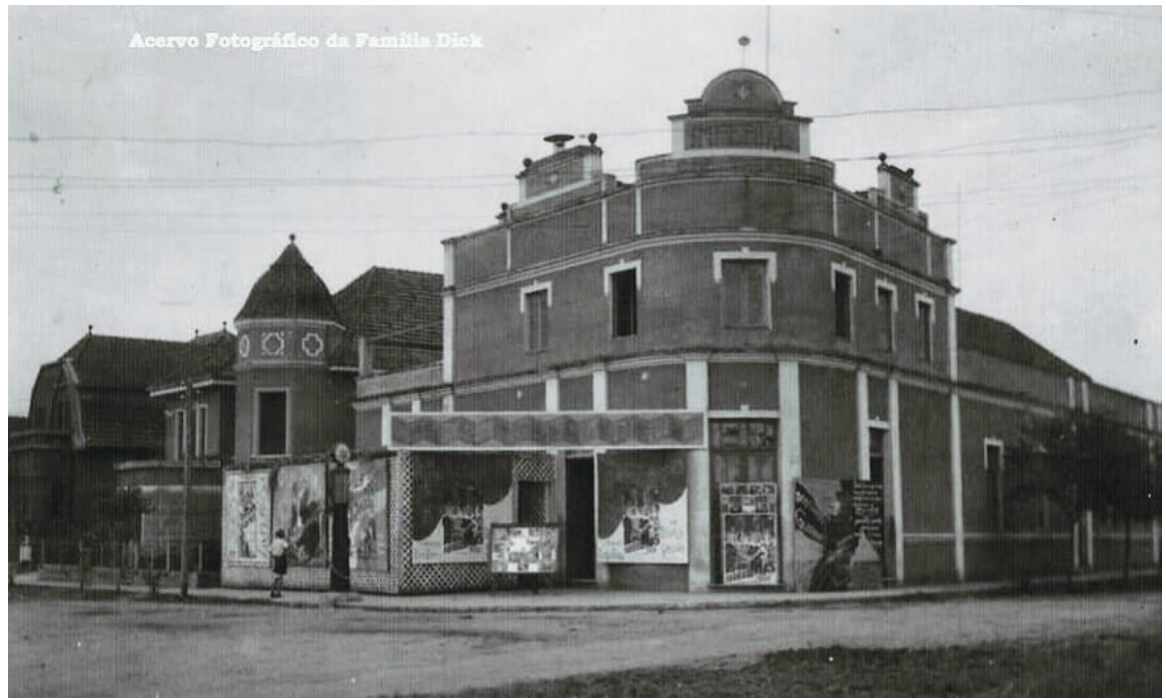

Fonte: Acervo fotográfico Família Dick

Além do cinema, os clubes tiveram um papel cultural importante para os antigos moradores e cidadãos. Neste ponto, destaca-se o Clube 15 de Novembro. Segundo Lang (1996), em 1911 os funcionários da empresa Irmãos Vetter fundaram o Esporte Clube 15 de Novembro, a fim de recreação e jogos esportivos, constituindo em 1917 a sociedade Concórdia. O prédio de 1917 possui arquitetura eclética, de influência da imigração alemã e pertence hoje ao patrimônio histórico de Campo Bom (LANG, 1996). O clube conta com três sedes e com um time de futebol que participa dos campeonatos estaduais, tendo já participado dos nacionais em anos anteriores.

O Clube Recreativo e Cultural Oriente também é um reservatório cultural e histórico. Tendo surgindo inicialmente em 1934 quando funcionários de fábricas locais e agricultores se uniram para criar um clube de futebol (LANG, 1996). Posteriormente este clube foi destinado a outros eventos culturais e sociais como bailes, festas e bolões. Por meio, destes clubes e do cinema, demonstra a expressiva importância que os moradores e colonizadores relegaram ao viéis social e cultural.

Outra emblemática peça urbana com história é a antiga Fábrica de calçados Irmãos Vetter (figura 11) que foi a primeira fábrica de calçados da cidade. Segundo a Prefeitura Municipal de Campo Bom esta fábrica foi criada por Jacob Vetter, em 1890, constituiu um importante mecanismo de crescimento econômico da vila e posteriormente do município. A 
prefeitura adquiriu o prédio e transformou a fachada do prédio em monumento da praça Largo irmãos Vetter (figura 12), juntamente com a torre-chaminé da antiga fábrica.

Figura 11 - Antiga Fábrica Irmãos Vetter Figura 12 - Fachada da Fábrica

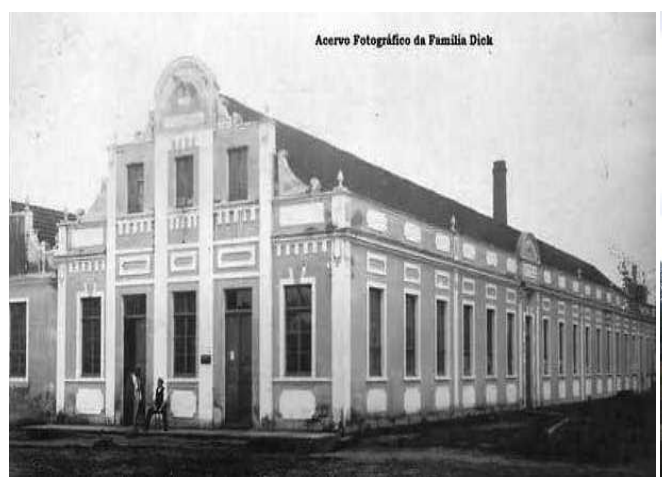

Fonte: Acervo fotográfico Família Dick

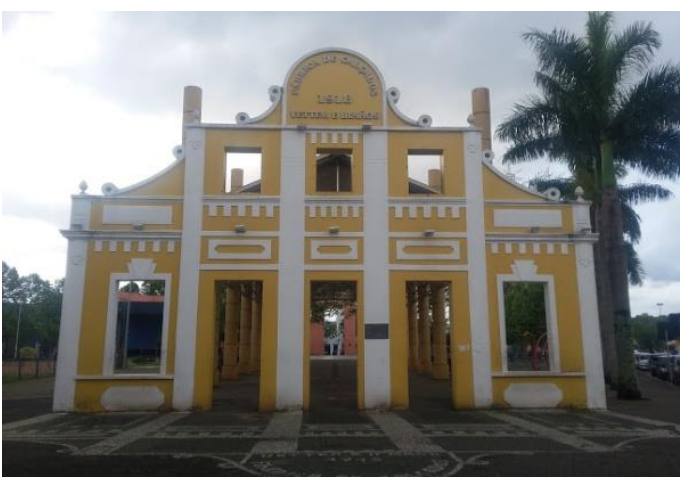

Fonte: Cenas Perdidas, 2017.

Ressalta-se que na década de 1990 inicia-se um inventário sobre os possíveis patrimônios culturais do município, denominado de: Inventário do Patrimônio Cultural de Campo Bom. A pesquisa inventariante iniciouse em 1994 e foi concluída em 1996, tendo como responsáveis a arquiteta Andréia Knewitz e o historiador Guido Lang e totalizou-se 57 bens, entre bens imóveis e equipamentos industriais como patrimônios (STOCKER JÚNIOR, 2014). Entre estes bens, pode-se notar uma heterogeneidade na composição tipológica: destacam-se 02 edificações enxaimel, 13 residências de "frontão recortado" e dois templos religiosos luteranos, todas estas edificações peculiares da arquitetura ou da história local, vinculadas a cultura teuto-brasileira, além do prédio de Sociedade Recreativa (Clube XV de Novembro), do prédio industrial (Fábrica Vetter), da Casa de Edith Blos e de duas edificações Art-Déco - Cinema Imperial e Banco da Província (STOCKER JÚNIOR, 2014).

Este mesmo autor escreve que o inventário de 1994 não garantiu a preservação dos bens, pois mesmo com o início do inventário houve a demolição de alguns dos imóveis e espaços arrolados no inventário, tais quais: a Villa Ida, Villa Julieta, casa de Edith Blos e casa de Pedro Blos Filho. Sem legislação específica ou respaldo no Plano Diretor da cidade, o inventário do patrimônio cultural anulou-se, e com o passar do tempo reduziu-se em um estudo e registro das edificações (STOCKER JÚNIOR, 2014). Assim, em Campo Bom não teve, até 2014, nenhum tipo de reconhecimento legal do seu patrimônio cultural, ou a aplicação de instrumentos que fomentem a preservação destes bens patrimoniais (STOCKER JÚNIOR, 2014). Das edificações que não foram demolidas, muitas se encontram em precárias condições de conservação, o que futuramente implicará em demolição. 
De acordo com os dados obtidos na pesquisa e na revisão de literatura notou-se que no início do inventário de patrimônio cultural do município, muitos proprietários com medo de não poder mais mexer nos imóveis antigos, demoliram estes, antes de se tornar bens tombados. Em muitos terrenos a demolição dos casarões antigos deu lugar a terrenos baldios e não a construções significativas, o que amplia a noção de temor a patrimonização da cidade. Esta questão reforça que além de inventários e ações patrimoniais as entidades público-administrativas precisam investir em educação patrimonial e fomentar iniciativas de ofertar aos proprietários dos imóveis mecanismos de conservação e lucratividade. Daí o incentivo ao turismo pode representar uma forma dos proprietários se envolverem com a causa da preservação da cultura e história local.

O avanço no contexto da conservação patrimonial em Campo Bom ganha ênfase com a constituição da Lei № 2494, de 29/07/2003, mas sem tantos ganhos representativos nas ações de tombamento e preservação patrimonial. Mais, recentemente, se percebe o desenvolvimento de ações mais concretas. Nesta linha, em 2016 novamente foi realizado outro inventário, chamado de Inventário do Patrimônio Arquitetônico e Paisagístico de Campo Bom, que foi entregue oficialmente ao Instituto do Patrimônio Histórico e Artístico do Estado do Rio Grande do Sul (IPHAE) na tentativa de buscar um reconhecimento dos bens da história e da cultura da construção de uma cidade e sociedade. Segundo a Prefeitura Municipal de Campo Bom no $61^{\circ}$ aniversário de emancipação do município, a Associação Pró-Memória do Patrimônio Histórico Cultural e Ambiental de Campo Bom e o Espaço Cultural Dr. Liberato promoveram a exposição "Campo Bom: Um Panorama Histórico". A exposição buscou mostrar a sociedade os bens patrimoniais.

A sociedade campobonense reconhece que a preservação patrimonial deve ser uma ação conjunta entre proprietários dos imóveis, sociedade e poder público, pois os bens são parte de uma coletividade, de uma história que precisa ser preservada para manter viva a história e as raízes culturais. Além disso, a comunidade reconhece alguns bens como patrimônio da cidade. Entre os bens reconhecidos pela sociedade em pesquisa exploratória foram elencados: a Casa Cinema Imperial, a Igreja Evangélica, casa Alfredo Blos, fachada da fábrica Irmãos Vetter, sede do Clube 15 de Novembro, Casa Arno Kunz, Casa Faller, Moinho Deuner, o Parcão, entre outras casas antigas e como bens intangíveis da cidade foi destacado: o pão de laranja.

Sobre o pão de laranja, Garcia; Zottis e Bonho (2015) escrevem que uma das manifestações alimentares herdadas pela imigração germânica em Campo Bom é "pão de laranja" (orangebrot), uma combinação do pão com a laranja e esta é considerada como patrimônio histórico/cultural imaterial do município por meio da lei no 4.191/2014. Para Batista et. al. (2014, apud GARCIA; ZOTTIS; BONHO, 2015), não existe uma receita padrão, cada família tem o seu modo de preparo, entretanto, a receita tem como base ingredientes, como farinha de trigo, óleo vegetal, sal, canela, laranjas, fermento e água. 
Outro bem imaterial do município de Campo Bom reconhecido, em 2018, como tal, por projeto de lei da Câmera Municipal, é o Rodeio Nacional de Campo Bom declarado como Patrimônio Cultural Imaterial do Município de Campo Bom. O rodeio é uma festividade bem conhecida e que integra a cultura gaúcha, assim como o Centro de Tradições Gaúchas (CTG) Campo Verde de Campo Bom é um dos que mais realiza eventos no Rio Grande do Sul.

Ademais, a população reconhece que os bens culturais estão virando "cinzas e escombros", que a maioria destes não pode ser visitada pela precária conservação; alguns bens, todavia, que são de domínio público ou coletivo, estão preservados e conservados, como a praça do Largo Irmãos Vetter, que abriga a fachada da antiga fábrica, a estação ferroviária, a igreja luterana e a Sede da comunidade do Clube 15 de Novembro.

O Parque da Integração Arno Kunz, popularmente conhecido como Parcão, também é um projeto urbano que deve ser revitalizado e salvaguardado, pois é um projeto urbano de referência, construído na década de 1950 e que até hoje apresenta uma função de lazer. O parcão é história e marca de uma sociedade que obteve sucesso urbano, com vários projetos urbanos reconhecidos no país e fora dele. E a sociedade reconhece o parcão como um bem púbico que merece ser conservado.

A antiga residência de Miguel Blos, hoje pertence ao município de Campo Bom, que busca por recursos para recuperar o local e transformálo em um museu municipal (JORNAL REPERCURSSÃO, 2018). Uma importante forma de aumentar o reconhecimento dos bens patrimoniais junto à comunidade e a instalação do turismo cultural/histórico futuramente.

A Praça João Blos de Campo Bom também é uma área de lazer com história, abrigava em décadas passada safariz com peixes e tartarugas, onde as crianças adoravam observar os peixes. Foram realizados muitos eventos locais nela. Hoje, a mesma apresenta outras configurações como mesas para jogar xadrez e espaço para lazer ao ar livre.

Ademais, a tradição dos imigrantes é preservada através da culinária e gastronomia, pela música e dança, promovidas pelo Centro Cultural Eintracht e pelo Glockenthal Volkstanzegruppe, bem como os eventos culturais (NUNES, 2017). Relevando que a música e dança também são elementos culturais meecedores de destaque na preservação social, parte da história e da herança alemã.

Diante disso, os agentes públicos têm iniciado o trabalho para salvaguardar o patrimônio, com iniciativas pontuais e iniciais, como os inventários, o tombamento da Igreja Luterana e as exposições da cultura e história do município. Contudo, é importante que estas medidas continuem a fazer parte do cotidiano dos campobonenses e inclusive o tombamento dos bens deve ser uma forma de concretizar a preservação. Haja vista a necessidade dos organismos públicos auxiliarem na conservação dos bens através de recursos públicos, já que os 
proprietários, em muitos casos, não têm o interesse de fazer a manutenção dos mesmos.

Destarte, a educação patrimonial poderia ser uma saída para que a população e os mais jovens campobonenses se interessassem pela manutenção dos antigos e remanescentes bens culturais e históricos. A possibilidade de preservação dos bens não deve ser apenas para guardar a história, que já é algo muito rico, mas para integrar perspectivas de turismo, porque o turismo traz visibilidade e renda o que certamente serão importantes na valorização dos bens patrimoniais. Mas, isto não significa a mercantilização do espaço, pois as memórias são coletivas e públicas. Além do mais não é simplesmente tombar os patrimônios que interessa na memória urbana, mas criar momentos de revitalizá-los com educação, exposição e outras ações de socialização patrimonial.

\section{CONSIDERAÇÕES FINAIS}

A preservação patrimonial adquire interesse no tratamento do espaço urbano contemporâneo, onde as formas antigas da cidade estão desaparecendo em função de novas construções. Pensar os patrimônios culturais e históricos das cidades têm sido um desafio da sociedade, gestores públicos e orgãos de pesquisa, pois nem sempre a sociedade reconhece e quer salvagardar suas mémorias e identidades. Por outro lado, quando a população quer salvaguardar os bens culturais e históricos existem entraves, como: a falta de verbas para revitalização, de legislação e fiscalização da preservação dos bens. A maioria das cidades brasileiras não tem um planejamento e uma política patrimonial consisa e concreta. Muitas cidades possui inventário, mas leis e medidas de preservação ainda são algo fora da realidade do planejamento urbano destas cidades.

Este é o contexto da cidade de Campo Bom, dos quais tem criado políticas, e realizado dois inventários sobre os bens culturais e históricos, porém encontra muitos desafios em diminuir a demolição das construções antigas da cidade, ou porque estas estão depredadas e em má conservação, ou devido à falta de interesse de uma parcela da população, inclusive dos proprietários dos imovéis. Esta condição é clara, pois entre a realização dos dois inventários, os proprietários de imóvens acabaram por demolir as casas antigas, por medo de perderem os imóveis, em função de um possível tombamento. Além disso, os tombamentos são recentes e ainda pouco expressivo.

Em contrapartida, a comunidade reconhece alguns bens culturais como patrimônios, dos quais foram elencados: o Cinema Imperial, a Igreja Luterana da Paz, a Estação ferroviária, a fábrica Irmãos Vetter, a Sociedade Quinze de Novembro, o Parção e como bens culturais imateriais: o rodeio e o pão de laranja. Mas, falta uma educação patrimonial e uma gestão pública que aplique medidas para a 
conservação e salvaguardo dos bens. Ainda, as construções antigas foram reformadas e conservadas pelos proprietários e comunidade, faltando uma interação com a gestão pública.

É importante reforçar que a cidade de Campo Bom foi formada a partir da colonização, sobretudo, alemã que impôs formas e estruturas no espaço que proporcionaram o desenvolvimento urbano e a criação de infraestruturas para expansão urbana. Estes elementos são fundamentais para se entender o espaço urbano e a atual conjuntura urbana, principalmente a expansão da urbanização do longo da avenida Brasil e o desenvolvimento da indústria calçadista e dos planos urbanos.

Portanto, a educação patrimonial e o incentivo ao turismo cultural tendem a fortalecer a preservação patrimonial dos bens que ainda sobreviveram à urbanização e à modernidade da cidade. Mas, ela exige que haja uma interação comunidade, poder público e instituições de ensino e pesquisa. Sendo significativo que os bens permaneçam ativos no espaço para evidenciar a mémoria, a história e a vida da cidade, no passado e no presente. Esta união fundamenta a visão da cidade para além do hoje, mas para um tempo que foi essencial para a expansão e formação do urbano.

Para finalizar, tão importante quanto as novas formas urbanas, as antigas contam uma história, um tempo que se cristalizou e pode ser passado para outras gerações. Além disso, a materialização do passado ganhará expressão no turismo cultural e no sentido de diferenciar as cidades, pelo conjunto arquitetônico, memórias, estruturas e dinâmicas urbanas.

\section{REFERÊNCIAS}

ABREU, M. de A. Sobre a memória das cidades. Território, ano III, n.4, jan./jun. de 1998.

GEOGRAFIA DO PASSADO: Rio de Janeiro, cidade portuária, século XVII. Revista GEOUSP, São Paulo, n. 7, p. 13-25, 2000.

ALMEIDA, M. G. de. Cultura, paisagens e patrimônio cultural: reflexões desde o Brasil central. Espaço \& Geografia, V.16, N. 2, p. 417 - 440, 2013.

AURELIO, C. R.; SCALABRINI, M. V. Patrimônio e cidade. "Sobrevivências" do passado em Ribeirão Pires.Arquitextos. Ano 04, maio 2004.

em:

https://vitruvius.com.br/revistas/read/arquitextos/04.048/587.

BARRETTO, M. Turismo e Legado Cultural: as possibilidades do planejamento. 2 ed. São Paulo: Papirus, 2000. (Coleção Turismo). 
BORBA, S. V. Transformações tecnológicas e estruturação intra-urbana: comparação entre duas cidades do Rio Grande do Sul.Indicadores $\begin{array}{llllll}\text { econômicos } & \text { FEE, } & \text { V. } & 23, & \text { N. } & 4,\end{array}$ Disponível: https://revistas.dee.spgg.rs.gov.br/index.php/indicadores/artic le/view/1026. Acesso em: 6 de maio de 2021.

CENAS PERDIDAS. Cenas Perdidas do Rio Grande do Sul e outros. 2017. Disponível em: < http://cenasperdidas.blogspot.com/2017>.

COPSTEIN, R. A evolução urbana de Campo Bom. Organon,Porto Alegre, v. 10, n. 10, 1964. Disponível em: https://seer.ufrgs.br/organon/article/view/38735. Acesso em 30 de jan. de 2021.

ELLWANGER, G. Campo Bom - Vista aérea - década 1980. 2019. Disponível em: https://prati.com.br/category/campo-bom.7

ESTAÇÕES FERROVIÁRIAS DO BRASIL. Município de Campo Bom, RS. 2020.2 Disponível em: http://www.estacoesferroviarias.com.br/rs_linhaspoa/campobom.html.

FERREIRA, O. M. Campo Bom: Colonização empreendedora. In: RIBEIRO, I. C. (Org.). Estudos em desenvolvimento regional II: pensando Campo Bom. Novo Hamburgo: Feevale, 2004.

FONSECA, T. P. da. Relatório de 1933 apresentado ao Interventor Federal dr. José Antônio Flores da Cunha. São Leopoldo: Rotermund, 1933.

GARCIA, R. K. DE O.; ZOTTIS, A. M.; BONHO, D. V. A gastronomia e seu uso turístico: a contribuição do projeto de extensão "turismo e gastronomia: unindo sabores e saberes" para a valorização do patrimônio cultural imaterial. Gestão e Desenvolvimento, Novo Hamburgo, vol. 12, n. 2, p. 67-82, julio-diciembre, 2015.

GREFFE, X. La valorisation économique du patrimoine. Paris, La Documentation Française, 2003.

JORNAL NH. Igreja luterana de Campo Bom agora é patrimônio histórico. 2021.

em: https://www.jornalnh.com.br/noticias/regiao/2021/01/20/igreja-luterana-decampo-bom-agora-e-patrimonio-historico.html

JORNAL REPERCUSSÃO. Restauro da Casa da Memória de Campo Bom aguarda por recursos do Ministério do Turismo para avançar. Seção dia a dia. Sapiranga, 2018. Disponível em: https://www.jornalrepercussao.com.br/dia-a-dia/restauro-da-casa-damemoria-de-campo-bom-aguarda-por-recursos-do-ministerio-do-turismopara-avancar. Acesso em: 30 de abr. de 2021. 
LANG, G. Campo Bom: História e Crônica - 1826/1996. Campo Bom: Papuesta, 1996.

LUMMERTZ, F. C. A cidade sem bens culturais: Uma Análise do Patrimônio Natural, da Natureza Intocada e a Ausência do Patrimônio Cultural na Cidade. In: XXVII Simpósio Nacional de História, Natal, 22 a 26 a julho de 2013.

MAIA, M. de C. T.; FARIAS FILHO, J. A. O patrimônio cultural tangível na construção da cidade sustentável. Revista Nacional de Gerenciamento de Cidades, v. 03, n. 16, 2015, pp. 172-189.

MANFIO, V. MEIER, M. A. A ciclovia: uma alternativa de mobilidade urbana da cidade de Campo Bom, RS, Brasil. In: 5ำ Fórum Goiano de Mobilidade Urbana e Trânsito. 2018. Anais... Cadernos de Resumo. Anápolis: UEG, 2018, p.49.

MAUTONE, M. (2001) (org.). I Beni culturali. Risorse per l'organizzazione del territorio. Bologna: Pàreon Editore Bologna, 729 p.

MENEZES, J. S. O patrimônio cultural da cidade de Ilhéus à luz da literatura de Jorge Amado. Cultur - Revista de Cultura e Turismo,llheús -

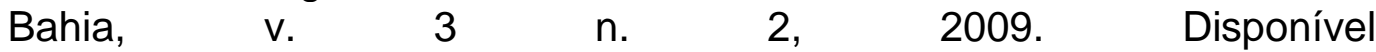
em: http://periodicos.uesc.br/index.php/cultur/about/contact.Acesso em: 4 de maio de 2021.

NUNES, R. de S. A tradição criativa como geradora de desenvolvimento socioeconômico em Campo Bom, RS, Brasil, no contexto das cidades criativas. 2017. 157f. Dissertação (Mestrado em Indústria Criativa) Universidade FEEVALE, Novo Hamburgo, 2017.

PINHEIRO, M. Valorização do Patrimônio histórico-cultural: uma perspectiva sustentável para o desenvolvimento turístico. In: RUSCHMANN, D. V. de M.; TOMELIN, C. A. (Orgs.). Turismo, ensino e práticas interdisciplinares. SP: Manole, 2013.

PREFEITURA MUNICIPAL DE CAMPO BOM. História da cidade. Disponível em: https://www.campobom.rs.gov.br/pt-br/historia-da-cidade. Acesso em: 10 de dez. de 2020.

Exposição Campo Bom: Um Panorama Histórico.Disponível em: https://www.campobom.rs.gov.br/ptbr/exposicao-campo-bom-um-panorama-historico. Acesso em: 12 de mar. de 2021.

RIBEIRO, C. R.; SIMÃO, M. C. R. Relações e contradições: direito à cidade e patrimônio urbano. In: III Encontro da Associação Nacional de Pesquisa e Pós-graduação em Arquitetura e Urbanismo arquitetura, cidade e projeto: uma construção coletiva São Paulo, 2014. Anais... São 
Paulo, 2014. Disponível em: http://www.anparq.org.br/dvd-enanparq3/htm/Artigos/ST/ST-EPC-007-5-RIBEIRO.SIMAO.pdf. Acesso em: 8 de maio de 2021.

SCHLÜTER, R. Gastronomia e Turismo. Coleção ABC do Turismo. São Paulo: Aleph, 2003.

SILVEIRA, M. da G. V. Uma análise da rede viária urbana caso de estudo: a cidade de Campo Bom. 2001. 139f. Dissertação (Mestrado em planejamento urbano e regional) - Universidade Federal do Rio Grande do Sul, Porto Alegre, 2001.

STOCKER JÚNIOR, J. L. Conhecer para (re)conhecer: Inventário do patrimônio edificado de Campo Bom (RS). 2014. Disponível em: https://www.academia.edu/34924887/Conhecer_para_re_conhecer_Inven t\%C3\%A1rio_do_patrim\%C3\%B4nio_edificado_de_Campo_Bom_RS. Acesso em: 20 de mar. de 2021.

VALLBONA, M. C; COSTA, M. P. (2003). Patrimonio Cultural. Madrid: Editora Síntesis, 689 p. 